\title{
Determination of 16 Selected Trace Elements in Children Plasma from China Economical Developed Rural Areas Using High Resolution Magnetic Sector Inductively Coupled Mass Spectrometry
}

\author{
Xiaobing Liu, Jianhua Piao, Zhenwu Huang, Shuang-Qing Zhang, Weidong Li, \\ Yuan Tian, and Xiaoguang Yang \\ Key Laboratory of Trace Element Nutrition, Ministry of Health, Department of Trace Element Nutrition, \\ National Institute of Nutrition and Food Safety, Chinese Center for Disease Control and Prevention, Beijing 100050, China \\ Correspondence should be addressed to Xiaoguang Yang; xgyangcdc@vip.sina.com
}

Received 28 November 2013; Revised 15 January 2014; Accepted 16 January 2014; Published 20 February 2014

Academic Editor: Feng Sun

Copyright (C) 2014 Xiaobing Liu et al. This is an open access article distributed under the Creative Commons Attribution License, which permits unrestricted use, distribution, and reproduction in any medium, provided the original work is properly cited.

\begin{abstract}
A rapid, accurate, and high performance method of high resolution sector field inductively coupled plasma mass spectrometry (HR-ICP-MS) combined with a small-size sample $(0.1 \mathrm{~mL})$ preparation was established. The method was validated and applied for the determination of 16 selected plasma trace elements (Fe, Cu, Zn, Rb, B, Al, Se, Sr, V, Cr, Mn, Co, As, Mo, Cd, and Pb). The linear working ranges were over three intervals, $0-1 \mu \mathrm{g} / \mathrm{L}, 0-10 \mu \mathrm{g} / \mathrm{L}$ and $0-100 \mu \mathrm{g} / \mathrm{L}$. Correlation coefficients $\left(R^{2}\right)$ ranged from 0.9957 to 0.9999 and the limits of quantification (LOQ) ranged from $0.02 \mu \mathrm{g} / \mathrm{L}(\mathrm{Rb})$ to $1.89 \mu \mathrm{g} / \mathrm{L}(\mathrm{Se})$. The trueness (or recovery) spanned from $89.82 \%(\mathrm{Al})$ to $119.15 \%$ (Se) and precision expressed by the relative standard deviation (RSD \%) for intra-day ranging from $1.1 \%$ (Zn) to $9.0 \%(\mathrm{Se})$, while ranged from $3.7 \%(\mathrm{Fe})$ to $12.7 \%(\mathrm{Al})$ for interday. A total of 440 plasma samples were collected from Chinese National Nutrition and Health Survey Project 2002 (CNNHS 2002), which represented the status of plasma trace elements for the children aged 3-12 years from China economical developed rural areas. The concentrations of 16 trace elements were summarized and compared by age groups and gender, which can be used as one of the basic components for the formulation of the baseline reference values of trace elements for the children in 2002
\end{abstract}

\section{Introduction}

The importance of trace elements and their role in biological cycling and homeostasis has become evident in recent years $[1,2]$, due to deficiency of essential trace elements or excess of potentially toxic elements accumulation in human body for a long time, which are responsible for various diseases [3]. So the formulation of trace elements reference values is indispensable prerequisite for the evaluation of body health, as well as the cost-effectiveness analysis [4].

Plasma is one of the preferred biological fluids and widely used for biomonitoring purposes in the surveys involving trace elements. But it is often limited by a small-size sample, complicated matrix, simultaneous multielemental analysis, and a wide range of concentrations of analytes from trace $(\mu \mathrm{g} / \mathrm{L})$ to ultratrace levels (ng/L-pg/L) [5]. Fortunately, high resolution sector field inductively coupled plasma mass spectrometry (HR-ICP-MS) is the most suitable equipment for the requirements because it exhibits an excellent sensitivity and precision, more superior ability to depress spectral interference, low volume sample consumption, and the rapid simultaneous analysis of multiple elements over a large range of concentrations [6]. Currently, the completed method of HR-ICP-MS combined with a simple-size biological sample preparation was established and applied for the multielemental analysis in practice, which can speed up analysis and limit potential sources of contamination.

So far, many studies involving trace elements across population have been carried out in different areas and countries, such as Italy [7, 8], Germany [9], UK [10], and Canada [11]. 
However, in China, there is no large-scale and multiregional survey including so many trace elements in population, especially in children, which is still scarce and fragmentary. However, children are usually faced with higher health risk of concern because of their special physiological susceptibility, behavior, lifestyles and dietary habits, and other related health factors [8]. In addition, many intervention programs involving trace elements on children had been conducted in recent years, but a partial cost-effectiveness analysis had not been performed for lacking of the original baseline values of trace elements. Therefore, the study to obtain the original baseline values of trace elements for children is really urgent and necessary, especially the different types of economic regions. Chinese National Nutrition and Health Survey Project 2002 (CNNHS 2002), which is a nationally representative and cross-sectional study, provides a good opportunity to examine the status of plasma trace elements of children in 2002.

The objectives of our study were to apply the optimized HR-ICP-MS combined with simple small-size sample preparation to determine 16 selected plasma trace elements $(\mathrm{Fe}, \mathrm{Cu}$, $\mathrm{Zn}, \mathrm{Rb}, \mathrm{B}, \mathrm{Al}, \mathrm{Se}, \mathrm{Sr}, \mathrm{V}, \mathrm{Cr}, \mathrm{Mn}, \mathrm{Co}$, As, Mo, Cd, and Pb) in children aged 3-12 years and to formulate the reference values of 16 selected trace elements, which could be considered as the original baseline levels for the representative children living in China economical developed rural areas in 2002.

\section{Experimental}

2.1. Materials and Reagents. High-pure water (18.2 $\Omega$ ) was obtained from TKA Gen-Pure apparatus (Gen-Pure TKA, Niederelbert, Germany). The electronic grade nitric acid $\left(\mathrm{HNO}_{3}\right)$ was used after additional purification by subboiling distillation in a PTFE still. Screw-capped polystyrene liners, $15 \mathrm{~mL}$ Corning Costar polypropylene centrifuge tubes were used for standard solution and sample preparation. All disposable pipette tips and plastic tubes were rigorously cleaned before use by immersion in $10 \%(\mathrm{v} / \mathrm{v}) \mathrm{HNO}_{3}$ and rising with high-pure water.

Single-element standard solutions of $1000 \mathrm{mg} / \mathrm{L}$ of $\mathrm{Fe}$, $\mathrm{Cu}, \mathrm{Zn}, \mathrm{B}, \mathrm{Al}, \mathrm{Se}, \mathrm{Mn}, \mathrm{Mo}, \mathrm{Co}, \mathrm{Cr}, \mathrm{Cd}, \mathrm{Sr}, \mathrm{Rb}, \mathrm{V}, \mathrm{Pb}$, and As were got from National Center for Standard Materials (Beijing, China). Internal standard elements, consisted of $1000 \mathrm{mg} / \mathrm{L}$ of Sc, Ga, Y, and Tl, were purchased from National Steel Materials Testing Center (Beijing, China). The certified reference materials used for internal quality control were Clichek Blood Plasma Control level 1 (Recipe, Munich, Germany).

\subsection{Instruments Setting and Optimization. The HR-ICP-MS} system was a Thermo Finnigan Element II model (Bremen, Germany) equipped with a $100 \mu \mathrm{L} / \mathrm{min}$ concentric glass nebulizer, a water-cooled Scott double-pass spray chamber, and torch with guard electrode device, nickel interface cones. The major ICP-MS operational settings were listed: RF power, 1280-1300 W; Argon gas flow rates, $16.0 \mathrm{~L} / \mathrm{min}$ (cool), $0.94 \mathrm{~L} / \mathrm{min}$ (auxiliary), and 1.110-1.200 L/min (sample); sample uptake rate, $0.1-0.2 \mathrm{~mL} / \mathrm{min}$. Daily instrument optimization was performed by monitoring the sensitivity and stability for masses ${ }^{7} \mathrm{Li},{ }^{115} \mathrm{In}$, and ${ }^{238} \mathrm{U}$ in tune solution. The resolution (300, 4000, and 10000) for elements was selected by the interference that happened in plasma samples. The interday and intraday stability of equipment were kept constant as much as possible. The percentage of oxides and doubly charged ion formation $\left(\mathrm{BaO}^{+} / \mathrm{Ba}\right.$ and $\mathrm{Ba}^{2+} / \mathrm{Ba}$ ratios) was maintained less than 0.003 and 0.03 , respectively.

\subsection{Preparation of Samples, Calibration Solutions, and Quality} Control. The plasma samples were stored in deep frozen state at $-80^{\circ} \mathrm{C}$ and kept very well without repeated freeze-thaw cycles prior to analysis. The selected plasma samples were reconstituted at room temperature, and then were shaken slightly and centrifuged at $2000 \mathrm{~g}$ for 15 minutes. $0.1 \mathrm{~mL}$ supernatant of plasma was diluted with $0.5 \%(\mathrm{v} / \mathrm{v}) \mathrm{HNO}_{3}$ and internal standard solutions in 1:20 (v/v) up to $2 \mathrm{~mL}$.

16 single-element standards ( $\mathrm{Fe}, \mathrm{Cu}, \mathrm{Zn}, \mathrm{Rb}, \mathrm{B}, \mathrm{Al}, \mathrm{Se}, \mathrm{Sr}$, $\mathrm{V}, \mathrm{Cr}, \mathrm{Mn}, \mathrm{Co}, \mathrm{As}, \mathrm{Mo} \mathrm{Cd}$, and $\mathrm{Pb}$ ) were mixed in the calibration solutions and diluted with $0.5 \%(\mathrm{v} / \mathrm{v}) \mathrm{HNO}_{3}$ and internal standard solutions and then prepared in correspondence to the concentrations of trace elements in human plasma.

The certified reference materials used for internal quality control were diluted according to the instructions of products, further prepared with $0.5 \% \mathrm{HNO}_{3}(\mathrm{v} / \mathrm{v})$. For those elements which are not certified in the commercially available samples, were performed by analyzing pooled plasma control samples fortified with appropriate aliquots (approximately 1times baseline level) of trace elements.

2.4. Samples of Analysis. 16 selected trace elements were determined by HR-ICP-MS using external standard quantification mode in class 1000 clean room. The determination of isotope was chosen according to the abundance, type of interference, and the amount of analytes expected in the matrix. For ${ }^{11} \mathrm{~B},{ }^{85} \mathrm{Rb},{ }^{88} \mathrm{Sr},{ }^{95} \mathrm{Mo},{ }^{111} \mathrm{Cd}$, and ${ }^{208} \mathrm{~Pb}$, the analyses were in low resolution (LR, $300 \mathrm{~m} / \Delta \mathrm{m}$ ), for ${ }^{27} \mathrm{Al}$, ${ }^{51} \mathrm{~V},{ }^{52} \mathrm{Cr},{ }^{55} \mathrm{Mn},{ }^{56} \mathrm{Fe},{ }^{59} \mathrm{Co},{ }^{63} \mathrm{Cu},{ }^{66} \mathrm{Zn}$, the analyses were in medium resolution (MR, $4000 \mathrm{~m} / \Delta \mathrm{m})$, and, for ${ }^{75} \mathrm{As}$ and ${ }^{77} \mathrm{Se}$, the analyses were in high resolution $(\mathrm{HR}, 10000 \mathrm{~m} / \Delta \mathrm{m})$. Internal standards $\left({ }^{45} \mathrm{Sc},{ }^{69} \mathrm{Ga},{ }^{89} \mathrm{Y}\right.$, and $\left.{ }^{205} \mathrm{Tl}\right)$ were used and the final concentrations were $10 \mu \mathrm{g} / \mathrm{L}$, which may provide adequate means for dealing with nonspectral interference and instrumental drifts [12].

2.5. Source of Plasma Samples. The plasma samples were chosen from the list of blood species established in CNNHS 2002 using a random stratified sampling procedure with proportional allocation by gender and age groups. A total of 440 plasma samples were selected from the children (boys: 232, girls: 208) with an age of $8.02 \pm 2.86$ years living in China economical developed rural areas, which was equal to approximately $10 \%$ of the children blood species in that area.

2.6. Statistical Analysis. The distribution of 16 selected trace elements was not normal according to KolmogorovSmirnov's tests. Basic descriptive statistics were estimated 
TABLE 1: 16 selected isotopes, linear working ranges and equations, correlation coefficient $\left(R^{2}\right)$, and limits of quantitation (LOQ) considering the dilution factor (dilution factor $=20$ ).

\begin{tabular}{lcccc}
\hline Isotope & Ranges $(\mu \mathrm{g} / \mathrm{L})$ & Linear equation $(\mathrm{conc}=a *$ signal $+b)$ & $R^{2}$ & LOQ $(\mu \mathrm{g} / \mathrm{L}, n=20)$ \\
\hline${ }^{11} \mathrm{~B}$ & $0-10$ & $y=1.425 e^{-004} x-2.770 e^{-003}$ & 0.9997 & 0.38 \\
${ }^{85} \mathrm{Rb}$ & $0-100$ & $y=9.255 e^{-001} x+6.444 e^{-002}$ & 0.9998 & 0.02 \\
${ }^{88} \mathrm{Sr}$ & $0-10$ & $y=1.113 e^{-004} x+3.690 e^{-002}$ & 0.9996 & 0.9989 \\
${ }^{95} \mathrm{Mo}$ & $0-1$ & $y=1.871 e^{-004} x+1.780 e^{-004}$ & 0.9979 & 0.03 \\
${ }^{111} \mathrm{Cd}$ & $0-1$ & $y=1.449 e^{-004} x-4.019 e^{-005}$ & 0.9989 & 0.03 \\
${ }^{208} \mathrm{~Pb}$ & $0-1$ & $y=1.056 e^{-003} x+2.229 e^{-003}$ & 0.9957 & 0.17 \\
${ }^{27} \mathrm{Al}$ & $0-2$ & $y=9.164 e^{-004} x+1.492 e^{-001}$ & 0.9989 & 0.24 \\
${ }^{51} \mathrm{~V}$ & $0-1$ & $y=1.560 e^{-003} x+1.059 e^{-003}$ & 0.9992 & 0.06 \\
${ }^{52} \mathrm{Cr}$ & $0-1$ & $y=1.289 e^{-003} x-6.643 e^{-003}$ & 0.9998 & 0.09 \\
${ }^{55} \mathrm{Mn}$ & $0-1$ & $y=1.807 e^{-003} x-4.863 e^{-003}$ & 0.9999 & 0.12 \\
${ }^{56} \mathrm{Fe}$ & $0-100$ & $y=1.592 e^{+000} x+6.966 e^{-001}$ & 0.9995 & 0.25 \\
${ }^{59} \mathrm{Co}$ & $0-1$ & $y=1.586 e^{-003} x-7.618 e^{-004}$ & 0.9999 & 0.06 \\
${ }^{63} \mathrm{Cu}$ & $0-100$ & $y=9.054 e^{-001} x-2.449 e^{-001}$ & 0.9996 & 0.48 \\
${ }^{66} \mathrm{Zn}$ & $0-100$ & $y=2.325 e^{-001} x+8.411 e^{-001}$ & 0.9969 & 0.45 \\
${ }^{75} \mathrm{As}$ & $0-1$ & $y=2.041 e^{-004} x-4.325 e^{-004}$ & 0.9973 & \\
${ }^{77} \mathrm{Se}$ & $0-10$ & $y=2.396 e^{-005} x-9.134 e^{-004}$ & & \\
\hline
\end{tabular}

from untransformed data including selected percentiles $\left(\mathrm{P}_{5}\right.$, $\mathrm{P}_{50}$, and $\mathrm{P}_{95}$ ), geometric mean (GM), and the $95 \%$ confidence interval of the geometric mean (95\% CI GM) of 16 selected trace elements for the children. Additionally, GM, 95\% CI GM of 16 selected trace elements was described by gender in conjunction with age groups. The differences caused by gender and age groups were identified with the MannWhitney $U$ test. A significant difference is $P<0.05$. All statistical analyses were completed by using the statistical package SPSS Base 20.0 (SPSS, Chicago, IL, USA).

\section{Results and Discussion}

3.1. Analytical Characteristics. The in-house method validation parameters were obtained and listed in Table 1. The working linear ranges were over at least 5 calibration points, which were divided into three ranges such as $0-100 \mu \mathrm{g} / \mathrm{L}, 0-$ $10 \mu \mathrm{g} / \mathrm{L}$, and $0-1 \mu \mathrm{g} / \mathrm{L}$. The linear equations were established by over 20 replicates per calibration solution indicating linearity between signal and concentration, and correlation coefficient $\left(R^{2}\right)$ ranged from $0.9957\left({ }^{27} \mathrm{Al}\right)$ to $0.9999\left({ }^{63} \mathrm{Cu}\right.$ and ${ }^{56} \mathrm{Fe}$ ). The limits of quantitation (LOQ) ranged from $0.02 \mu \mathrm{g} / \mathrm{L}\left({ }^{85} \mathrm{Rb}\right)$ to $1.89 \mu \mathrm{g} / \mathrm{L}\left({ }^{77} \mathrm{Se}\right)$, calculated as $10 \mathrm{SD}$ above the value for $0.5 \% \mathrm{HNO}_{3}$ solution $(n=20)$ plus the dilution factor, which in this case was 20 , considering the matrix effects and the excellent sensitivity of HR-ICP-MS.

Table 2 shows the trueness (or recovery) and precision of method, which were performed by checking against values given by the certified reference materials and by testing against pooled plasma samples fortified with a known quantity of reference standards. The resulting trueness (or recovery) spanned from $89.82 \%(\mathrm{Al})$ to $119.15 \%$ (Se). The precision was expressed by calculating the relative standard deviance $($ RSD $\%=$ (standard deviance/Mean $) \times 100)$ for intraday and interday, respectively. The RSD\% for intraday indicated the stability of the determination in one day (one sample preparation, 10 replicate measurements of the same sample) and the RSD\% for interday indicated the stability of the determination in 10 consecutive days (10 different sample preparations, 10 measurements in different days) [13]. The precision ranged from $1.1 \%(\mathrm{Zn})$ to $9.0 \%$ (Se) in $\mathrm{RSD} \%$ for intraday and $3.7 \%(\mathrm{Fe})$ to $12.7 \%(\mathrm{Al})$ in $\mathrm{RSD} \%$ for interday.

As shown above, the optimization method of HR-ICPMS combined with the simple sample preparation with $0.5 \%$ $\mathrm{HNO}_{3}$ was applied for the determination of 16 selected trace elements from ng/L to $\mu \mathrm{g} / \mathrm{L}$ ranges. The 20 -fold dilution causes the minor fluctuation at low concentrations for certain trace elements, but the method was reliable for the validation of methodological parameters and there was no coagulation or precipitation of plasma matrix components resulting in tubing or nebulizer blockages during $12 \mathrm{~h}$ of analysis. Compared with the other analytical procedures $[12,14]$, the method using $0.5 \% \mathrm{HNO}_{3}$ directly diluted in $1: 20(\mathrm{v} / \mathrm{v})$ is more rapid and free of contamination, especially in $0.1 \mathrm{~mL}$ volume of small-size sample consumption, low LOQ, and high sample throughput HR-ICP-MS, which can provide more flexibility in multielemental analysis.

3.2. Trace Elements Reference Values in Children Plasma. 16 selected trace elements for 440 plasma samples are successfully determined and the detailed results are summarized in Table 3. The concentrations of $\mathrm{Cd}, \mathrm{Pb}, \mathrm{V}, \mathrm{Cr}$, and As are usually very low (ng/L), even below the LOQ. During the analysis, the concentration of $\mathrm{Al}$ in plasma sample is still easily affected because of its ubiquitous, so that the rigorous control of exogenous contamination is of great importance. 
TABLE 2: Trueness (or recovery) and precision of the certified reference materials and the fortified pooled plasma analysis.

\begin{tabular}{|c|c|c|c|c|c|c|}
\hline \multirow{2}{*}{ Element } & \multirow[b]{2}{*}{$\begin{array}{l}\text { Reference } \\
\text { materials }\end{array}$} & \multicolumn{2}{|c|}{ Concentrations $(\mu \mathrm{g} / \mathrm{L})$} & \multicolumn{2}{|c|}{ RSD (\%) } & \multirow[b]{2}{*}{ Trueness/recovery (\%) } \\
\hline & & Certified/spiked & Measured & $\begin{array}{l}\text { Intraday } \\
(n=10)\end{array}$ & $\begin{array}{c}\text { Interday } \\
(n=10)\end{array}$ & \\
\hline Mo & Recipe level 1 & $1.82 \pm 0.09$ & $1.92 \pm 0.12$ & 3.2 & 8.8 & 105.49 \\
\hline $\mathrm{Cd}$ & Recipe level 1 & $2.37 \pm 0.12$ & $2.25 \pm 0.10$ & 4.1 & 9.3 & 94.73 \\
\hline V & Recipe level 1 & $1.45 \pm 0.7$ & $1.61 \pm 0.03$ & 4.7 & 10.9 & 111.22 \\
\hline $\mathrm{Cr}$ & Recipe level 1 & $3.56 \pm 0.18$ & $3.78 \pm 0.12$ & 3.8 & 5.6 & 106.25 \\
\hline $\mathrm{Co}$ & Recipe level 1 & $2.20 \pm 0.11$ & $2.31 \pm 0.06$ & 3.7 & 9.6 & 105.09 \\
\hline $\mathrm{Cu}$ & Recipe level 1 & $871.00 \pm 43.55$ & $835.01 \pm 19.72$ & 1.3 & 9.7 & 95.87 \\
\hline $\mathrm{Zn}$ & Recipe level 1 & $925.00 \pm 46.25$ & $873.12 \pm 14.57$ & 1.1 & 8.7 & 94.39 \\
\hline As & Recipe level 1 & $47.80 \pm 2.40$ & $52.75 \pm 2.92$ & 7.7 & 10.9 & 110.36 \\
\hline $\mathrm{Se}$ & Recipe level 1 & $80.00 \pm 4$ & $95.32 \pm 6.59$ & 9.0 & 11.2 & 119.15 \\
\hline B & Pooled & 24.04 & 23.57 & 3.7 & 10.8 & 98.04 \\
\hline $\mathrm{Rb}$ & Pooled & 244.3 & 254.21 & 2.8 & 9.6 & 104.06 \\
\hline $\mathrm{Sr}$ & Pooled & 36.4 & 33.51 & 2.4 & 7.9 & 92.03 \\
\hline $\mathrm{Pb}$ & Pooled & 0.42 & 0.39 & 4.8 & 8.6 & 92.85 \\
\hline $\mathrm{Al}$ & Pooled & 3.83 & 3.54 & 7.4 & 12.7 & 89.82 \\
\hline $\mathrm{Mn}$ & Pooled & 2.38 & 2.44 & 3.3 & 4.5 & 102.52 \\
\hline $\mathrm{Fe}^{\#}$ & Pooled & 407.02 & 417.84 & 1.5 & 3.7 & 102.66 \\
\hline
\end{tabular}

${ }^{\#}$ Spike 0.5-times baseline.

TABLE 3: Concentrations of 16 selected plasma trace elements in children $(N=440)$ aged 3-12 years from China economical developed rural areas.

\begin{tabular}{|c|c|c|c|c|c|c|}
\hline \multirow{2}{*}{ Element } & \multirow{2}{*}{$n<\mathrm{LOQ}$} & \multicolumn{3}{|c|}{ Percentiles $(\mu \mathrm{g} / \mathrm{L})$} & \multirow{2}{*}{$\mathrm{GM}(\mu \mathrm{g} / \mathrm{L})$} & \multirow{2}{*}{$95 \%$ CI GM $(\mu \mathrm{g} / \mathrm{L})$} \\
\hline & & $P_{5}$ & $P_{50}$ & $P_{95}$ & & \\
\hline B & 0 & 16.13 & 33.86 & 94.88 & 36.44 & $34.40-38.72$ \\
\hline $\mathrm{Rb}$ & 0 & 173.61 & 360.73 & 1281.50 & 405.80 & $384.50-428.62$ \\
\hline $\mathrm{Sr}$ & 0 & 30.33 & 58.40 & 95.99 & 56.63 & $54.71-58.85$ \\
\hline Mo & 0 & 1.48 & 2.30 & 3.97 & 2.36 & $2.28-2.42$ \\
\hline $\mathrm{Cd}^{\mathrm{a}}$ & 59 & $<$ LOQ & 64.53 & 176.11 & $64.53^{\mathrm{b}}$ & $59.86-68.42^{\mathrm{b}}$ \\
\hline $\mathrm{Pb}^{\mathrm{a}}$ & 9 & 217.0 & 576.14 & 1989.82 & 599.53 & $563.66-643.05$ \\
\hline $\mathrm{Al}$ & 47 & $<\mathrm{LOQ}$ & 1.40 & 8.87 & $1.40^{\mathrm{b}}$ & $1.12-1.71^{\mathrm{b}}$ \\
\hline $\mathrm{V}^{\mathrm{a}}$ & 46 & $<$ LOQ & 116.09 & 277.58 & 114.32 & $108.45-121.17$ \\
\hline $\mathrm{Cr}^{\mathrm{a}}$ & 6 & 137.70 & 408.22 & 6819.27 & 538.41 & $484.40-804.82$ \\
\hline $\mathrm{Mn}$ & 0 & 0.77 & 1.51 & 6.24 & 1.77 & $1.66-1.90$ \\
\hline $\mathrm{Fe}$ & 0 & 660.68 & 1304.13 & 2565.59 & 1375.51 & $1313.36-1442.48$ \\
\hline $\mathrm{Co}^{\mathrm{a}}$ & 56 & 64.73 & 195.94 & 452.46 & 181.94 & $171.64-193.73$ \\
\hline $\mathrm{Cu}$ & 0 & 673.26 & 974.01 & 1386.36 & 972.21 & $951.79-993.61$ \\
\hline $\mathrm{Zn}$ & 0 & 557.27 & 765.31 & 1027.16 & 754.74 & $741.47-770.39$ \\
\hline As & 68 & $<\mathrm{LOQ}$ & 1.17 & 7.14 & 1.51 & $1.37-1.68$ \\
\hline Se & 0 & 68.52 & 119.80 & 173.16 & 116.32 & $113.33-119.53$ \\
\hline
\end{tabular}

${ }^{\mathrm{a}} \mathrm{ng} / \mathrm{L},{ }^{\mathrm{b}}$ median and CI median.

The further description of 16 selected plasma trace elements in children is presented by gender and age groups, which are listed in Tables 4 and 5.

Comparing between 3-6 years children and 7-12 years children, most of the GM concentrations of trace elements are higher for 3-6 years children with some exceptions (Rb, $\mathrm{Sr}, \mathrm{Cd}, \mathrm{As}$, and $\mathrm{Se}$ ) in boys and with some exceptions (Rb, $\mathrm{Sr})$ in girls. Overall, the concentrations of $\mathrm{Cr}(Z=-2.622$, $P<0.01), \mathrm{V}(Z=-2.728, P<0.01), \mathrm{Mn}(Z=-2.470$,
$P<0.05)$, and $\mathrm{Cu}(Z=-6.071, P<0.001)$ for $3-6$ years children are significantly higher than $7-12$ years children. The concentrations of $\mathrm{V}(Z=-2.478, P<0.05)$ and $\mathrm{Cu}(Z=$ $-3.900, P<0.001)$ for $3-6$ years children are significantly higher than 7-12 years children in boys, and the concentration of $\mathrm{Cu}$ is significantly higher in girls $(Z=-4.479, P<0.001)$.

In a comparison between boys and girls, the concentrations of $\mathrm{B}(Z=-2.908, P<0.01)$, $\mathrm{Sr}(Z=-2.587, P<0.01)$, and $\mathrm{Fe}(Z=-3.186, P<0.001)$ for boys are significantly 
TABLE 4: Concentrations $(\mu \mathrm{g} / \mathrm{L})$ of 16 selected plasma trace elements in boys $(N=232)$ by age groups.

\begin{tabular}{|c|c|c|c|c|c|c|}
\hline \multirow{2}{*}{ Element } & \multirow{2}{*}{ GM } & \multirow{2}{*}{$95 \%$ CI GM } & \multicolumn{2}{|c|}{$3-6$ years $(n=71)$} & \multicolumn{2}{|c|}{$7-12$ years $(n=137)$} \\
\hline & & & GM & 95\% CI GM & GM & 95\% CI GM \\
\hline B & 33.4 & $31.30-35.99$ & 35.51 & $31.70-40.53$ & 32.31 & $29.56-35.55$ \\
\hline $\mathrm{Rb}$ & 395.89 & $368.26-425.68$ & 362.34 & $324.79-400.17$ & 415.14 & $375.44-462.18$ \\
\hline $\mathrm{Sr}$ & 54.46 & $51.98-57.16$ & 54.01 & 50.31-57.91 & 54.71 & $51.45-58.31$ \\
\hline Mo & 2.40 & $2.31-2.50$ & 2.48 & $2.33-2.63$ & 2.36 & $2.25-2.48$ \\
\hline $\mathrm{Cd}^{\mathrm{ab}}$ & 64.53 & $59.46-70.70$ & 58.88 & $52.19-70.46$ & 67.67 & $60.71-73.95$ \\
\hline $\mathrm{Pb}^{\mathrm{a}}$ & 596.42 & $548.41-657.44$ & 641.92 & $541.96-770.01$ & 573.36 & $518.40-640.28$ \\
\hline $\mathrm{Al}^{\mathrm{b}}$ & 1.34 & $1.05-1.71$ & 1.62 & $1.06-2.67$ & 1.12 & $0.90-1.61$ \\
\hline $\mathrm{V}^{\mathrm{a}}$ & 112.51 & $103.75-122.17$ & 132.53 & $117.09-152.93$ & 103.05 & $92.87-113.43$ \\
\hline $\mathrm{Cr}^{\mathrm{a}}$ & 576.33 & $495.71-680.52$ & 748.1 & $563.83-1047.27$ & 501.07 & $419.89-602.85$ \\
\hline $\mathrm{Mn}$ & 1.72 & $1.56-1.88$ & 1.89 & $1.63-2.22$ & 1.63 & $1.45-1.83$ \\
\hline $\mathrm{Fe}$ & 1274.32 & $1191.60-1372.53$ & 1371.04 & $1224.06-1546.84$ & 1225.29 & $1131.34-1345.05$ \\
\hline $\mathrm{Co}^{\mathrm{a}}$ & 180.72 & 165.17-197.94 & 194.61 & 175.05-217.05 & 173.68 & $154.22-195.23$ \\
\hline $\mathrm{Cu}$ & 987.4 & $958.50-1016.89$ & 1072.5 & $1029.30-1120.49$ & 944.57 & $911.40-978.38$ \\
\hline $\mathrm{Zn}$ & 760.51 & 743.07-778.79 & 773.31 & $743.78-802.74$ & 753.73 & $731.43-777.40$ \\
\hline As & 1.54 & $1.34-1.79$ & 1.42 & $1.17-1.77$ & 1.61 & $1.33-1.97$ \\
\hline $\mathrm{Se}$ & 118 & $113.91-122.26$ & 117.15 & $110.06-125.08$ & 118.45 & $113.50-123.57$ \\
\hline
\end{tabular}

TABLE 5: Concentrations $(\mu \mathrm{g} / \mathrm{L})$ of 16 selected plasma trace elements in girls $(N=208)$ by age groups.

\begin{tabular}{|c|c|c|c|c|c|c|}
\hline \multirow{2}{*}{ Element } & \multirow{2}{*}{ GM } & \multirow{2}{*}{$95 \%$ CI GM } & \multicolumn{2}{|c|}{$3-6$ years $(n=71)$} & \multicolumn{2}{|c|}{$7-12$ years $(n=137)$} \\
\hline & & & GM & 95\% CI GM & GM & 95\% CI GM \\
\hline B & 40.17 & $36.81-43.96$ & 42.52 & $36.98-48.67$ & 39.0 & $35.29-43.66$ \\
\hline $\mathrm{Rb}$ & 417.16 & $383.77-453.30$ & 390.64 & $333.78-459.67$ & 431.6 & $390.49-481.66$ \\
\hline $\mathrm{Sr}$ & 59.15 & $56.10-62.61$ & 58.4 & $53.31-64.03$ & 59.53 & $55.65-63.55$ \\
\hline Mo & 2.30 & $2.20-2.40$ & 2.41 & $2.22-2.61$ & 2.25 & $2.15-2.36$ \\
\hline $\mathrm{Cd}^{\mathrm{ab}}$ & 64.21 & $57.25-70.45$ & 65.51 & $59.05-77.20$ & 61.06 & $54.40-67.51$ \\
\hline $\mathrm{Pb}^{\mathrm{a}}$ & 603.01 & $548.67-665.21$ & 666.89 & $562.87-795.59$ & 572.36 & $514.27-641.99$ \\
\hline $\mathrm{Al}^{\mathrm{b}}$ & 1.46 & $1.01-2.01$ & 1.53 & $1.17-2.16$ & 1.36 & $0.85-2.12$ \\
\hline $\mathrm{V}^{\mathrm{a}}$ & 116.37 & $107.83-125.76$ & 128.86 & $115.05-143.77$ & 110.38 & $99.51-122.55$ \\
\hline $\mathrm{Cr}^{\mathrm{a}}$ & 499.04 & $436.04-577.73$ & 589.53 & $462.01-762.18$ & 457.76 & $392.96-543.89$ \\
\hline $\mathrm{Mn}$ & 1.83 & $1.67-2.02$ & 2.00 & $1.68-2.40$ & 1.75 & $1.56-1.97$ \\
\hline $\mathrm{Fe}$ & 1497.88 & 1402.61-1611.11 & 1582.55 & $1399.60-1815.70$ & 1455.8 & $1339.46-1585.82$ \\
\hline $\mathrm{Co}^{\mathrm{a}}$ & 183.31 & $170.64-196.81$ & 193.74 & $171.97-220.78$ & 178.13 & $161.80-195.06$ \\
\hline $\mathrm{Cu}$ & 955.54 & $926.00-985.77$ & 1047.22 & $979.18-1112.75$ & 911.23 & 883.09-939.70 \\
\hline $\mathrm{Zn}$ & 748.36 & $728.40-769.65$ & 773.29 & $739.76-813.93$ & 735.75 & $713.39-759.50$ \\
\hline As & 1.47 & $1.28-1.70$ & 1.51 & 1.16-1.97 & 1.45 & $1.24-1.69$ \\
\hline $\mathrm{Se}$ & 114.47 & $110.23-118.89$ & 116.14 & $108.86-123.86$ & 113.62 & $107.82-119.16$ \\
\hline
\end{tabular}

lower than girls, and the concentrations of $\mathrm{B}(Z=-2.371$, $P<0.05)$, Sr $(Z=-2.072, P<0.05)$, and Fe $(Z=-2.844$, $P<0.01)$ are obviously lower in $7-12$ years boys.

In general, in the children who lived in fixed areas for a long period of time without any major changes, the status of trace elements is representative and relatively stable. Age and gender are the major factors that affect the body burden of trace elements. Furthermore, the plasma trace elements usually associate with the age and gender after controlling for other potential confounders [15]. Age-related changes may be caused by behavior, dietary habits, and lifestyle. Genderrelated changes might rely on a specific source of exposure in one sex or due to the difference in physiological factors or metabolic pathways. Comparing the status of trace elements in plasma of our study with other previous studies [14, 16, 17], most of trace elements such as B, Rb, Sr, Mo, V, Cr, Mn, Fe, $\mathrm{Co}, \mathrm{Cu}, \mathrm{Zn}$, and Se are mostly similar to the wide ranges reported before and only the concentrations of $\mathrm{Cd}, \mathrm{Al}, \mathrm{Pb}$, and As are at relatively low levels, which may be correlated with the surroundings. In addition, the limitation of this study is a 
relatively small sampling, which should be expanded in future studies.

\section{Conclusion}

In this study, we have established the method for the determination of 16 selected plasma trace elements in children. The method, combining HR-ICP-MS with the simply diluted $0.5 \% \mathrm{HNO}_{3}$ by $1: 20(\mathrm{v} / \mathrm{v})$, is an excellent method for rapid, free-contamination, small-size sample requirement and enough low LOQ for the most of plasma trace elements analysis. In addition, the concentrations of 16 selected plasma trace elements of the children from China economical developed rural areas were determined. The first representative data can be used as one of the basic components for the formulation of original baseline reference values of trace elements for the children aged 3-12 years in 2002, which can be helpful in the subsequent health evaluation and the costeffectiveness analysis of health intervention programs.

\section{Conflict of Interests}

The authors declare that there is no conflict of interests regarding the publication of this paper.

\section{References}

[1] N. B. Ivanenko, A. A. Ivanenko, N. D. Solovyev, A. E. Zeimal, D. V. Navolotskii, and E. J. Drobyshev, "Biomonitoring of 20 trace elements in blood and urine of occupationally exposed workers by sector field inductively coupled plasma mass spectrometry," Talanta, vol. 116, pp. 764-769, 2013.

[2] P. Heitland and H. D. Köster, "Biomonitoring of 37 trace elements in blood samples from inhabitants of northern Germany by ICP-MS," Journal of Trace Elements in Medicine and Biology, vol. 20, no. 4, pp. 253-262, 2006.

[3] C. G. Fraga, "Relevance, essentiality and toxicity of trace elements in human health," Molecular Aspects of Medicine, vol. 26, no. 4-5, pp. 235-244, 2005.

[4] C. Muñiz Sariego, J. L. Fernández-Martin, J. M. MarchanteGaýon, J. I. García Alonso, J. B. Cannata-Andía, and A. SanzMedel, "Reference values for trace and ultratrace elements in human serum determined by double-focusing ICP-MS," Biological Trace Element Research, vol. 82, no. 1-3, pp. 259-272, 2001.

[5] B. Bocca, A. Lamazza, A. Pino et al., "Determination of 30 elements in colorectal biopsies by sector field inductively coupled plasma mass spectrometry: method development and preliminary baseline levels," Rapid Communications in Mass Spectrometry, vol. 21, no. 11, pp. 1776-1782, 2007.

[6] M. Krachler, "Environmental applications of single collector high resolution ICP-MS," Journal of Environmental Monitoring, vol. 9, no. 8, pp. 790-804, 2007.

[7] B. Bocca, R. Madeddu, Y. Asara, P. Tolu, J. A. Marchal, and G. Forte, "Assessment of reference ranges for blood $\mathrm{Cu}, \mathrm{Mn}$, Se and $\mathrm{Zn}$ in a selected Italian population," Journal of Trace Elements in Medicine and Biology, vol. 25, no. 1, pp. 19-26, 2011.

[8] A. Pino, A. Amato, A. Alimonti, D. Mattei, and B. Bocca, "Human biomonitoring for metals in Italian urban adolescents: data from Latium Region," International Journal of Hygiene and Environmental Health, vol. 215, no. 2, pp. 185-190, 2012.

[9] P. Heitland and H. D. Köster, "Biomonitoring of 37 trace elements in blood samples from inhabitants of northern Germany by ICP-MS," Journal of Trace Elements in Medicine and Biology, vol. 20, no. 4, pp. 253-262, 2006.

[10] M. A. White and E. Sabbioni, "Trace element reference values in tissues from inhabitants of the European Union. X. A study of 13 elements in blood and urine of a United Kingdom population," Science of the Total Environment, vol. 216, no. 3, pp. 253-270, 1998.

[11] D. A. Haines and J. Murray, "Human biomonitoring of environmental chemicals - early results of the 2007-2009 Canadian Health Measures Survey for males and females," International Journal of Hygiene and Environmental Health, vol. 215, no. 2, pp. 133-137, 2012.

[12] B. Bocca, A. Alimonti, G. Forte et al., "High-throughput microwave-digestion procedures to monitor neurotoxic elements in body fluids by means of inductively coupled plasma mass spectrometry," Analytical and Bioanalytical Chemistry, vol. 377, no. 1, pp. 65-70, 2003.

[13] P. Heitland and H. D. Köster, "Biomonitoring of 30 trace elements in urine of children and adults by ICP-MS," Clinica Chimica Acta, vol. 365, no. 1-2, pp. 310-318, 2006.

[14] P. Avino, G. Capannesi, M. Manigrasso, E. Sabbioni, and A. Rosada, "Element assessment in whole blood, serum and urine of three Italian healthy sub-populations by INAA," Microchemical Journal, vol. 99, no. 2, pp. 548-555, 2011.

[15] E. Bárány, I. A. Bergdahl, L.-E. Bratteby et al., “Trace elements in blood and serum of Swedish adolescents: relation to gender, age, residential area, and socioeconomic status," Environmental Research, vol. 89, no. 1, pp. 72-84, 2002.

[16] J.-P. Goullé, L. Mahieu, J. Castermant et al., "Metal and metalloid multi-elementary ICP-MS validation in whole blood, plasma, urine and hair: reference values," Forensic Science International, vol. 153, no. 1, pp. 39-44, 2005.

[17] A. Alimonti, F. Petrucci, F. Laurenti, P. Papoff, and S. Caroli, "Reference values for selected trace elements in serum of term newborns from the urban area of Rome," Clinica Chimica Acta, vol. 292, no. 1-2, pp. 163-173, 2000. 

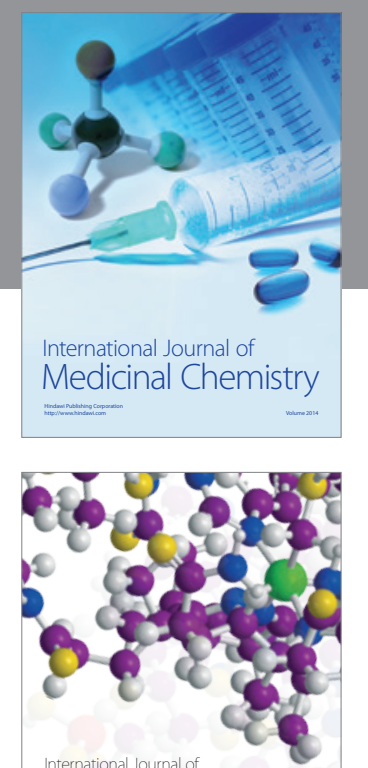

\section{Carbohydrate} Chemistry

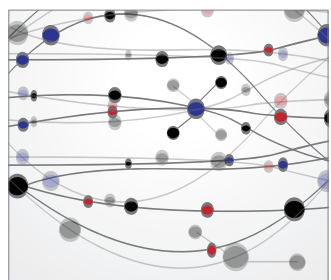

The Scientific World Journal
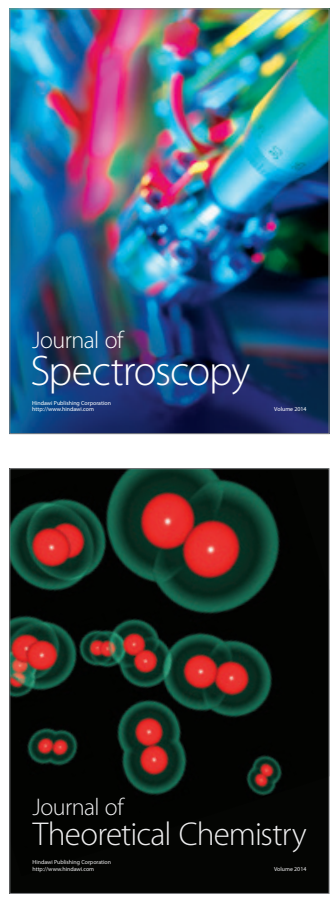
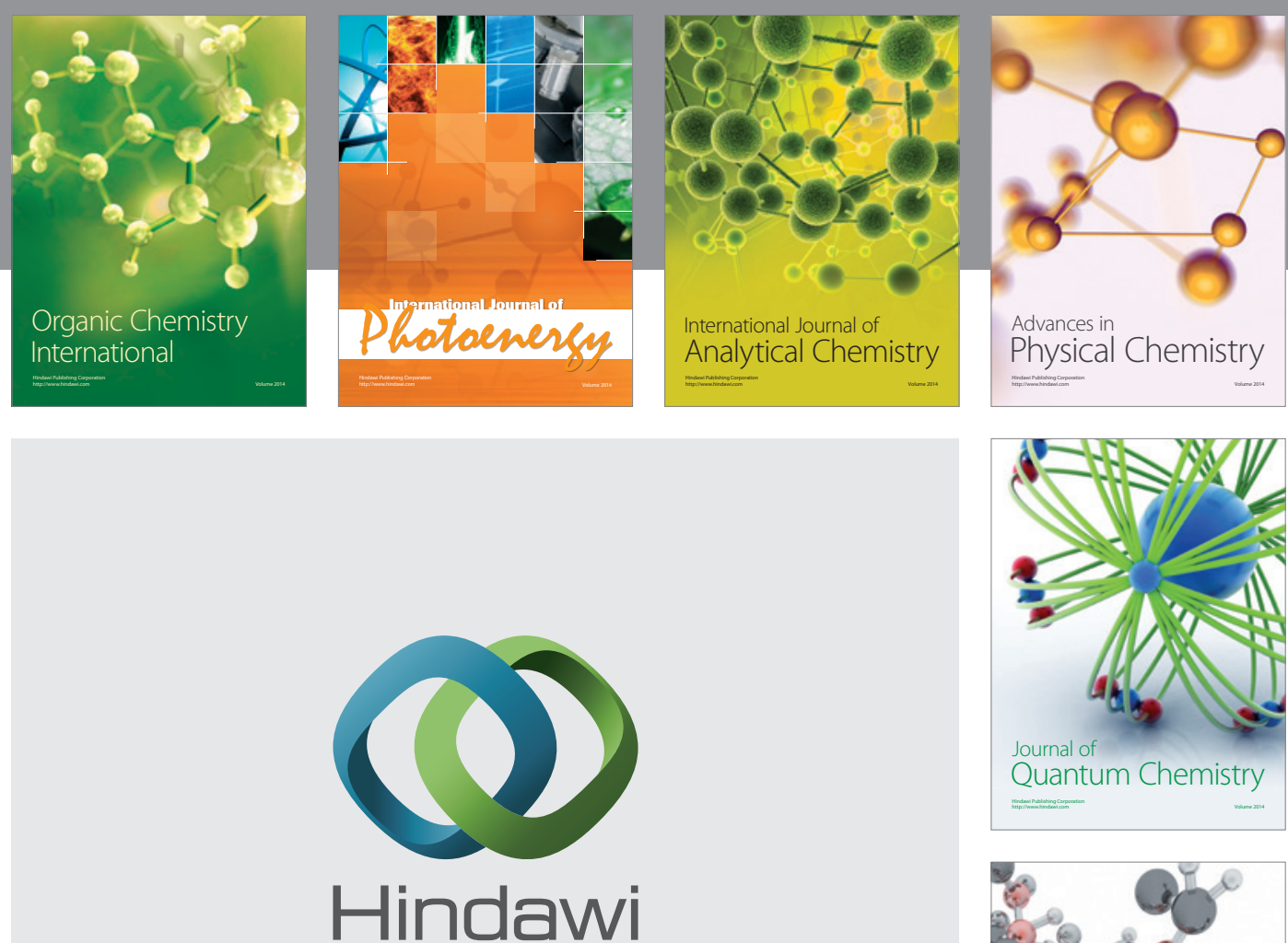

Submit your manuscripts at

http://www.hindawi.com

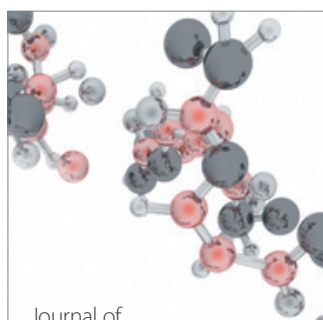

Analytical Methods

in Chemistry

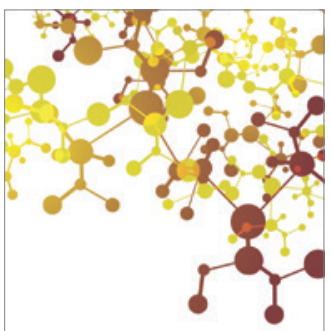

Journal of

Applied Chemistry

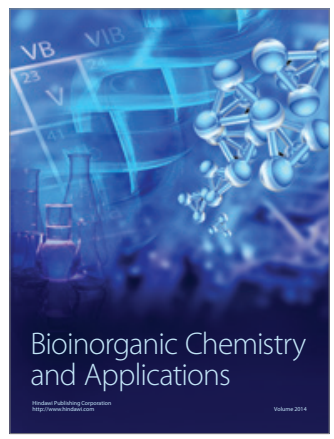

Inorganic Chemistry
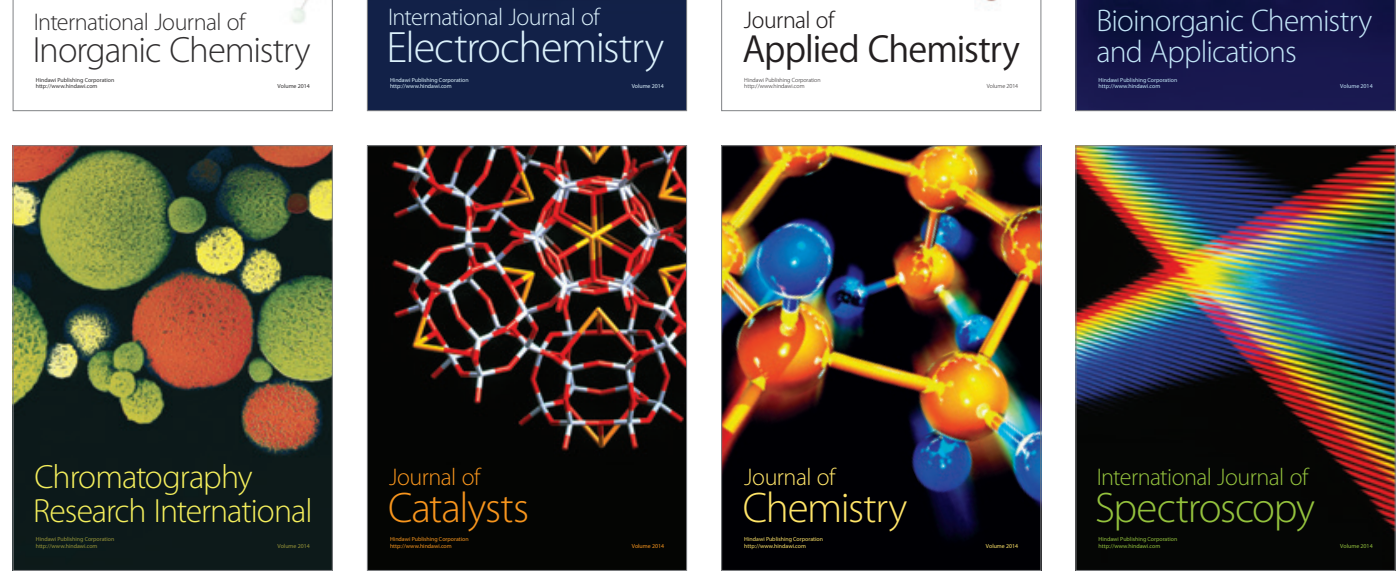